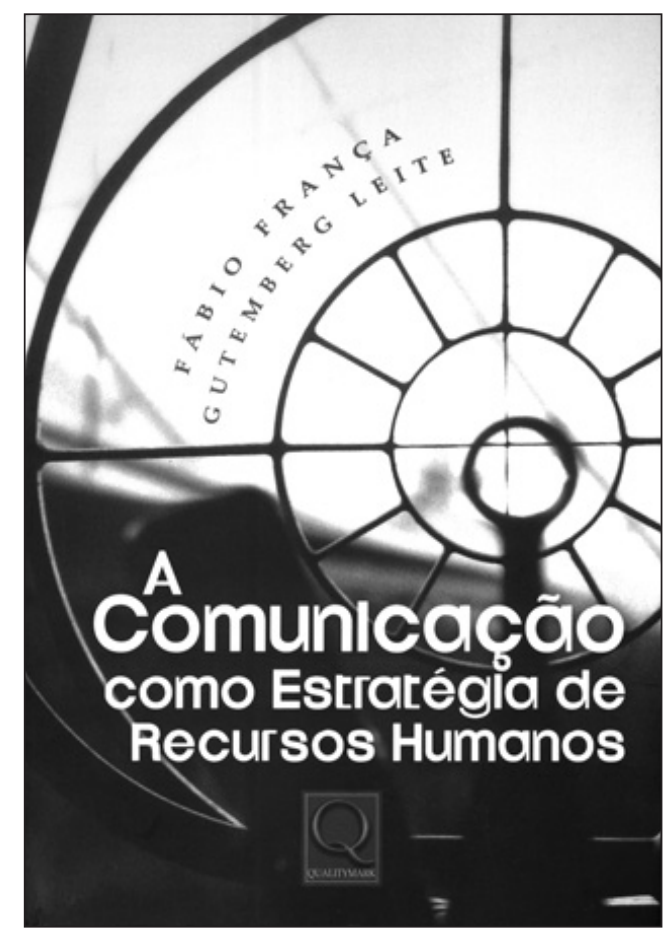

Fábio França e Gutemberg Leite

A comunicação como estratégia de recursos humanos

Rio de Janeiro:

Qualitymark, 2007.

185 páginas

Luiz Alberto de Farias

- Doutor em Comunicação e Cultura pelo Programa de Pós-Graduação em Integração da América Latina (Prolam) da Universidade de São Paulo (USP)

- Mestre em Comunicação e Mercado pela Faculdade Cásper Líbero

- Especialista em Teoria da Comunicação pela Faculdade Cásper Líbero

- Graduado em Relações Públicas pela Faculdade Cásper Líbero

- Graduado em Jornalismo pela Universidade Cruzeiro do Sul

- Professor-doutor da Escola de Comunicações e Artes da Universidade de São Paulo (ECA-USP)

- Professor-titular da Faculdade Cásper Líbero

- Professor-adjunto da Universidade Cruzeiro do Sul

- Diretor-administrativo da Intercom (Sociedade Brasileira de Estudos Interdisciplinares da Comunicação)

- Diretor-administrativo da Abrapcorp (Associação Brasileira de Pesquisadores de Relações Públicas e Comunicação Organizacional)

- Presidente da Associação Brasileira de Relações Públicas (ABRP-SP)

- Editor do Jornal Intercom

- Editor da Organicom

- lafarias@usp.br 


\section{Comunicação desatando nós}

té onde vai a área de recursos humanos em uma organização? Para os que acreditam que empresas são antes de tudo um conjunto de pessoas, e sem as quais não se pode chegar a lugar algum, o famoso RH está em tudo e em todos. Isso já seria um motivo para grande polêmica e diáspora, pois a obra criada por Fábio França e Gutemberg Leite propõe exatamente a união do RH com a comunicação, outra área cujos defensores e praticantes professam como onipresente.

Para os autores de A comunicação como estratégia de recursos humanos, há muito mais que muros e separações. Ao contrário, há uma verdadeira sintonia entre as duas partes. A comunicação pode ser elemento de orientação para a efetividade e eficiência dos processos de relacionamento entre os públicos que compõem uma organização.

Focados em uma percepção contemporânea das relações humanas no contexto do mundo empresarial, França e Leite debruçam-se em posições como a gestão de pessoas baseada em competências e de habilidades, sem, no entanto, deixar de lado a evolução dos conceitos e das teorias que fundaram e fundamentaram área de recursos humanos.

Os autores são velhos conhecidos das duas áreas e talvez por isso um resultado tão harmonioso tenha sido obtido nesta obra. Enquanto o Dr. Fábio França trafega pelo campo da comunicação há algumas décadas, tanto no campo empresarial quanto no acadêmico, o Prof. Gutemberg Leite atua há diversos anos na gestão de pessoas.

Um aspecto que vale a pena destacar em A comunicação como estratégia de recursos humanos é o aspecto da globalização como elemento de forte influência nos contornos das relações humanas dentro de qualquer meio, em especial no ambiente empresarial.

O livro trata também de questões como a emoção na comunicação e de aspectos como assertividade e liderança nas comunicações. Aprofundando-se no quesito comunicação, os autores tratam de comunicação dirigida e mídia no ambiente empresarial.

Dentre os nove capítulos que compõem o livro, França e Leite destacam ainda pesquisas por eles realizadas (uma quantitativa e duas qualitativas) com o objetivo de terem a compreensão de públicos essenciais no desenvolvimento do pensamento em recursos humanos. Foram ouvidos profissionais que atuam na área de recursos humanos, empresários e consultores do setor, e, por fim, editores e articulistas que publicam na área de RH. 
Os autores não poderiam encerrar o livro sem deixar uma minuciosa orientação sobre como tornar possível um planejamento de comunicação que envolva os objetivos das áreas de recursos humanos.

Em tempos nos quais a organização precisa estar em sintonia com os constantes e crescentes movimentos de transformação, os professores França e Leite convidam, com esse trabalho, seus leitores a uma minuciosa reflexão na qual a organização seja um sistema em que todos têm absoluta responsabilidade sobre o que se passa. A visão de integração entre comunicação e recursos humanos ajuda a desatar nós, a criar relacionamentos e a otimizar, inclusive, processos de gestão de crises.

Se assim é se assim lhe parece, comunicar de forma adequada e planejada permite gerenciar os relacionamentos internos e trabalhar para melhorias nos impactos externos da identidade corporativa. A comunicação como estratégia de recursos humanos é um guia para unir teoria e prática no dia-a-dia das organizações. Assim me parece. 